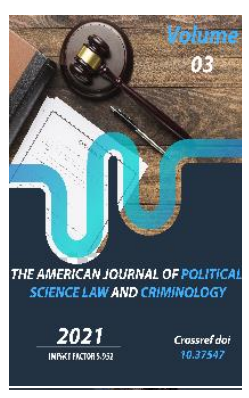

\title{
Ways Of Ensuring The Profile Of Offenses And Its Legal Consequences
}

\author{
Khudayberdieva Gulnora Amanmurodovna \\ Associate Professor, Candidate Of Legal Sciences, Specialized Branch Of Tashkent State \\ University Of Law , Uzbekistan
}

Journal Website: http://usajournalshub.c om/index,php/tajpslc

Copyright: Original content from this work may be used under the terms of the creative commons attributes 4.0 licence.

\section{ABSTRACT}

In this article, the legal nature of offenses, the tasks before the profiling of offenses, the ways of carrying out profiling, the legal views of scientists on the fight against offenses, ensuring the rule of law in the prevention and fight against offenses, ensuring the effectiveness of the reforms carried out, further improvement of legislation, the fight against crime and the tasks facing law-enforcement

\section{KEYWORDS}

Law, rule of law, offense, prophylactics, application of law, Fight Against Crime.

\section{INTRODUCTION}

Since the day Uzbekistan gained its independence, it has aimed at strengthening its independence comprehensively and forming a strong civil society. Independence, first of all, was strengthened by the creation of a system for the Prevention of violations and effective fight against crime, and today shows positive results. 
Today, as society develops, it can be seen that the ways of committing offenses are also becoming more complicated. Therefore, the role of effective organization and implementation of the profile of committed violations is important not only the internal affairs bodies, but also all law-enforcement bodies, as well as the role of public cooperation.

The profile of offenses is the most effective, humane, low-capital direction of combating offenses, in particular, crime. Accordingly, at present, the practice of combating crime sets out the task of studying the issues of profiling offenses theoretically more strictly.

The main task of the profile of offenses is to raise legal consciousness and legal culture in society, to strengthen legality, to identify, study and take measures to eliminate the causes of the occurrence of offenses and the conditions that allow them.

The fact is that the phenomenon of offenses arose at the time when state and law institutions appeared and will always exist together with them, we will not be mistaken. Only the scale of the offense is manifested at a higher or lower level, depending on the "conditions" created for itself in a certain space and time. Therefore, the fight against violations, especially its dangerous appearance - crime, has historically been one of the main tasks of every society and state.

"When it comes to offenses, administrative responsibility is understood as the implied, guilty, inhuman act (act or omission)" [1]. It can be seen from this that it is necessary to give a correct understanding of the phenomena and processes that perform the role of causes and conditions that prevent violations as an object phenomenon, based on the law of the unit of dependence of dialectics.

"The smart legislator cares not about the punishment for the violation, but for the Prevention of violations. He tries not to punish for the offense, but to improve morality"[2].

In the strategy of action on five priority areas of development of the Republic of Uzbekistan in 2017-2021,"priority direction of provision of rule of Law and reform of the judicial system of law "is defined as the second direction" increasing the effectiveness of coordination of activities on combating crime and Prevention of offenses " [3].

It is known that the prophylactics of offenses is the most effective, humane, low - cost direction of combating offenses, in particular, crime. At present, the practice of combating crime sets out the task of studying the issues of profiling offenses theoretically more strictly. "The prophylactics of offenses is a social - legal science that studies the essence, features and legalities of the prophylactics of offenses, develops measures to increase the effectiveness of prophylactics of offenses, and provides practice of combating offenses with them [4].

The teachings on the profiling of offenses are "a set of ideas, opinions, views and points of view on the profiling of offenses, including the elimination of their causes and conditions" [5].

The tasks related to the profile of offenses are, in turn, conditioned to increase the effectiveness of participation of public structures in the fight against crime and prophylactics of offenses by the internal affairs bodies of the Republic, Organization of mutually targeted cooperation on the basis of 
advanced experience in the activities of all law enforcement bodies and other organizations.

"Prevention of offenses is primarily a fight against disorder and mind-altering habits, that is, it is necessary to build society so that it can fight against the mind-altering, distorted morals, customs and habits"[6]. If we look at the history of development in the years of independence of the profile of offenses, then along with the formation of the legal basis of the profile of offenses, the theoretical and methodological basis of the profile of offenses was formed. Scientific research carried out in the field of profiling offenses in the years of independence directly serves as the theoretical and methodological basis of the national system of profiling offenses of Uzbekistan.

An example of the adoption of a number of laws on the formation of legal bases of prophylactics of offenses can be cited. In particular, the Republic of Uzbekistan "on the mandatory treatment of patients suffering from chronic alcoholism, drug addiction or intoxication", "on the profile of uncontrolled and delinquent behavior among minors", "on the restriction of distribution and consumption of alcohol and tobacco products", "on social partnership", "on the fight against the spread of the disease (HIV infection) caused by the human immunodeficiency virus" on the", Laws" on protection of children from information damaging to their health " and others are becoming more important.

The adoption of the law of the Republic of Uzbekistan "on the prophylactics of offenses" dated May 14, 2014 has determined the regulation of relations in the field of prophylactics of offenses. In particular, the functions of organs and institutions carrying out the prophylactics of offenses and participating in it were shown. In this law, the profile of uncontrolled violations and offenses among minors - the offenses were strengthened as a separate type of special profiling.

Of course, as long as the appropriate measure of influence on him is not taken after the commission of the offense, the cases of respect for the laws, obedience in society will continue to disappear on their own. No cases of any major or minor irregularities have arisen, a measure of influence on such cases is mandatory. This is followed by an increase in social responsibility for behavior in society, as well as an increase in legal consciousness and culture. In which society there is no measure of influence over the cases of any offenses, the fact that the same society is gradually social disintegration, the Crimean situation is aggravated, and eventually society becomes an unregulated Society system based on "barbarous" relations. Therefore, as long as the rule of law in society and all are equally responsible before the law, it is known from history to all of us that in this society there is an increase in the mood of discontent, causing various unrest.

"The appointment of a penalty for committing an offense not only prevents individuals from committing an offense, but also is beneficial for those who have committed an offense to a certain extent of punishment, cleanses the heart of those who have committed an offense through punishment " [7].

Amir Temur says in his plan to rule the kingdom: "I have commanded that thieves and robbers should be punished on the basis of" the law " and that the mischief-makers, the corrupt, the evil-doers should be driven out of the country. Do not leave Nagornyy people in 
regions and cities. Guider to every city and village, so that the guide of horses will guard over the presidency, and whoever steals something, the responsibility for it shall be upon him"[8].

The individual profile of violations is determined taking into account the individual characteristics of the individual, his or her social environment, socio-household conditions and lifestyle, the personality's enthusiasm, his or her tendency to commit a violation, as well as other factors that characterize the degree of social danger of the committed violation. Individual prophylactics of offenses of a complex and restrictive nature are used on the grounds provided for by law [9].

In the general profile of violations, the implementation of the following measures is established, including:

- Development and implementation of state programs and other programs related to the profile of offenses;

- Legal promotion among the population;

- To identify, eliminate the causes of the occurrence of violations and the conditions that allow them, as well as to make presentations on the causes of the occurrence of violations and on the elimination of the conditions that allow them.

It is known that there are several types of prophylactics of violations. For example, the special profile of offenses and the basis for its implementation are "the special profile of offenses related to the profile of certain types of offenses of organs and institutions that directly carry out the prophylactics of offenses, the development and implementation of special measures aimed at eliminating the causes of the occurrence of these types of offenses and the conditions

For the implementation of a special profile of violations, the following will be the basis:

An increase in the number of certain types of offenses, categories of persons;

The occurrence of risks and threats that encroach on public safety and public order, the interests of the individual, society and the state.

Individual profiling of offenses, the conditions and grounds for its application are specified in Article 28 of the law, according to which "the bodies and institutions that directly carry out the profiling of offenses are motivated to commit inhuman acts, offenses, to identify persons who committed offenses, to keep their accounts and to exert educational influence on them is the individual profiling of offenses.

Individual profiling of offenses is determined taking into account the individual, the peculiarities of the individual, his social environment, his socio-household conditions and lifestyle, the person's tendency to commit an offense, abnormal behavior, as well as other factors that characterize the degree of social danger of the committed offenses.

For the application of an individual profile of offenses, the existence of reliable information about the person's abnormal social behavior, his tendency to commit an offense, or the fact that he committed an offense, becomes the basis.

Individual profiling of offenses of a complex and restrictive nature is applied on the grounds 
provided for by law. "Individual prophylactic measures of offenses consist of a professional interview, official warning, notification of the reasons for the occurrence of offenses and the conditions that allow them, social rehabilitation and social adaptation, taking into account the prophylactic, sending them to compulsory treatment, administrative control."

There are also major and additional, object or sub-object types of offenses cause and conditions in the criminological literature [11].

Victim prophylactics of offenses these are prophylactic measures aimed at reducing the risk that certain individuals become victims of offenses or crimes by the bodies carrying out prophylactics of offenses, in which the following measures are carried out:

It is possible to achieve a great effect in the Prevention of "suicide" through this method of conducting prophylactic activities, taking into account the individual and socio-psychological characteristics of the individual in relation to the victims of offenses, and secondly, to take measures to identify and protect the victims from offenses, to teach the legal methods of resolving the conflict situation among the Organization of specialized institutions providing assistance to victims of offenses, for example, providing legal, socio-material, rehabilitation assistance to them by placing on the street unattended or uncontrolled minors, invalids, elderly people in the appropriate specialized institutions;

Development and implementation of special sex measures aimed at ensuring the physical and psychological safety of the victim from violations, informing him about the methods and means of self-defense provided for by law;
The regular control of places (territories) where abnormal behavior is observed relatively often or where offenses often occur as an example, it is necessary to carry out a victim prophylactic procedure in these places by regularly controlling the places where a lot of phloxes are collected, where illegal currencies and precious metals are pre-sold, and so on, where there will be a lot of other;

Provide legal training and education to the population through the widespread dissemination of information about the necessary defense and the latest necessity in the event of an attack on citizens;

The organization of trust, fast communication phones, rescue services in the presence of a body or institution that directly carries out the profiling of offenses in order to obtain information about offenses committed or committed in the densely populated areas, on the subjects and geniuses of the population and other social (educational institutions, religious institutions, bus stations and railway stations, airports);

Organization of public discussions of projects of prophylactics programs and events, Organization of websites, blogs, chats in the World Internet Information Network and other social networks in order to identify and eliminate problems and shortcomings in the process of their implementation;

Dissemination of electronic literature on modern methods of profiling offenses, placing prophylactic banners, posters and other similar materials on crime and offenses in populated areas in order to prevent offenses and crimes against the population.

As a result of the effective functioning of the system of profiling offenses, law enforcement 
in the country is strengthened, the situation in the Crimea is significantly improved. This ensures that citizens live a peaceful and peaceful life. [12].

In the criminological literature, there are also Main and additional, object or sub-object types of the causes and conditions of offenses.

On the basis of the resolution of the president of the Republic of Uzbekistan dated April 18, 2017 № pp-2896 "on measures to radically improve the activities of the Departments of the prophylactics of offenses of Internal Affairs bodies "radically reformed the activities of the internal affairs bodies on the early prophylactics and Prevention of offenses.

In conclusion, we can say that in addition to law-enforcement agencies such as the internal affairs, the prosecutor's office, the state security service, the Justice, the state Customs Service, the state tax service, as well as the lawenforcement agencies in ensuring the effectiveness of the profile of offenses, the state bodies of social protection of Labor and population, the state bodies, active participation of non-profit organizations and citizens is important. This serves to carry out work on the profiling of offenses through systematic and impactful actions.

It is impossible to formulate the ideas of Justice, Development, obedience with respect to the laws in this society, in the end, when the appropriate measure of influence is applied in the case of any violation of the law.

\section{REFERENCES}

1. Sh.The A. Ganiev. Improvement of administrative responsibility for offences against morality. - What?: TDYUI. 2016 - 60 p.
2. Aphorisms and proverbs of compatriots and foreign scientists / Sh. Translation of abdurazzakova. - What?, 1989. - What? 256257.

3. Decree of the president of the Republic of Uzbekistan on measures to ensure more effective organization of the process of acquisition of rights over land parcels and other immovable property as part of the South Caucasus pipeline expansion project more ..., ,- № 6, 70-m.

4. Tursunov A.S., Fazilov I.No, it's not., Khodjakulov S.The B. Profilactics of offenses. / Textbook. - What?: Academy of the Ministry of Internal Affairs of the Republic of Uzbekistan, 2018. 47B.47B.

5. The X.The T.Zire " Lost In Test MatchThe T.Tolteev and others. Theory of state and law. Textbook / - T.: Academy of Mia of the Republic of Uzbekistan . 2009.- Twenty-six P.

6. Criminology. General part: textbook for higher education institutions of Mia / I. Ismailov, Q.The R. Abdurasulova, I.No, it's not. Fazilov. - What?: Academy of Mia of the Republic of Uzbekistan, 2015. - 28 B.

7. Plato (Plato) (m.the A. 428-347) / / http://ziyouz.uz/old/hikmatlar/mumtozfaylasuf / -428b.

8. Timur tuzukları /from Forscha a. Sağuni, H. Karomatov translation. - What?: 1991. - 95 B.

9. Sh.The A. Ganiev .Improvement of administrative responsibility for offences against morality. - What?: TDYUI. 2016 - 60 p.

10. The A.S. Tursunav, I.No, it's not. Fazilov, S.The B. Khujaqulov. Profilactics of offenses. / Textbook.- What?: Academy of Mia of the Republic of Uzbekistan . 2009.

11. Ismailov I., Ziyadullaev M.The $Z$. Organization of activities and cooperation 
The American Journal of Political Science Law and Criminology (ISSN - 2693-0803)

Published: April 30, 2021 | Pages: 150-156

Doi: https://doi.org/10.37547/tajpslc/Volume03Issue04-23

of profilactics in the base units of internal affairs bodies: educational-practical guide. - What?: Academy of Mia of the Republic of Uzbekistan, 2017.

12. Criminology. General part: textbook for higher education institutions of Mia / I. Ismailov, Q. The R. Abdurasulova, I. No, it's not. Fazilov; responsible editor Sh.The T. It's a treat. - What?: Academy of Mia of the Republic of Uzbekistan, 2015. - 94 B. 